\title{
RESPON INVESTOR ATAS SINYAL LABA, PELUANG BERTUMBUH, STRUKTUR MODAL, DAN UKURAN PERUSAHAAN PADA PERUSAHAAN MANUFAKTUR DI BEI PERIODE 2014-2018.
}

\author{
Jessica \\ Ari Hadi Prasetyo* \\ Program Studi Akuntansi, Kwik Kian Gie School of Business, Jl. Yos Sudarso Kav. 87, Jakarta 14350
}

\begin{abstract}
This study aims to examine the financial performance of public companies viewed from the effects of earnings persistence, growth opportunities, profitability, capital structure, and company size that affect market response to earnings information measured using earnings response coefficient (ERC). In the perspective of Signaling theory, management releases information related to the company's performance for investors regarding the company's actual fundamental condition. Companies that have a competitive advantage and good financial performance, have the potential to generate high profits because the company able to manage its resources in the perspective of Resources Based Theory, but in the context of Agency Theory the agent's relationship with the principal, causes agency problems due to differences in interests caused agency conflict. This study uses a sample of 31 manufacturing companies listed on the Indonesia Stock Exchange (IDX) during the 2014-2018 period. Based on the results of the regression analysis, it can be concluded that there are enough dependent variables together that significantly influence the earnings response coefficient. The results of this study indicate enough evidence is found that earnings persistence has a positive effect on ERC. Also, growth opportunities influence ERC and give a negative direction. While the capital structure, profitability and size of the company were not found enough evidence of influence on ERC.
\end{abstract}

Keywords: earnings persistence, growth opportunities, capital structure, profitability, company size, and earnings response coefficient.

\begin{abstract}
Abstrak
Penelitian ini bertujuan untuk meneliti kinerja perusahaan publik dilihat dari aspek persistensi laba, peluang pertumbuhan, profitabilitas, struktur modal, dan ukuran perusahaan yang mempengaruhi respon pasar terhadap informasi laba yang diukur menggunakan earnings response coefficient (ERC). Dalam perspektif signalling theory manajemen melepas informasi terkait kinerja perusahaan bagi investor mengenai kondisi fundamental perusahaan yang sebenarnya. Perusahaan yang memiliki memiliki keunggulan kompetitif dan kinerja keuangan yang baik, berpotensi menghasilkan laba yang tinggi karena perusahaan dapat mengelola sumber dayanya dengan baik dalam sudut pandang Resources Based Theory, namun dalam konteks Agency Theory hubungan agent dengan principal, menyebabkan masalah keagenan karena terjadinya perbedaan kepentingan yang menyebabkan terjadinya konflik keagenan. Penelitian ini menggunakan sampel 31 perusahaan manufaktur yang terdapat di Bursa Efek Indonesia (BEI) selama periode 2014-2018. Berdasarkan hasil analisis regresi dapat disimpulkan terdapat cukup variable dependen secara bersama sama berpengaruh secara signifikan terhadap earnings response coefficient. Hasil penelitian ini menunjukkan ditemukan cukup bukti bahwa persistensi laba berpengaruh positif terhadap ERC. Serta, peluang pertumbuhan berpengaruh terhadap ERC dan memberikan arah yang
\end{abstract}

\footnotetext{
*Alamat kini: Institut Bisnis dan Informatika Kwik Kian Gie, Jl. Yos Sudarso Kav. 87, Jakarta 14350

Penulis untuk Korespondensi: Telp. (021) 65307062 Ext. 708, Email: arihadi.prsetyo@kwikkiangie.ac.id
} 
negatif. Sedangkan struktur modal, profitabilitas dan ukuran perusahaan tidak ditemukan cukup bukti berpengaruh terhadap ERC.

Kata kunci : Persistensi laba, Peluang pertumbuhan, Struktur modal, Profitabilitas, Ukuran perusahaan, dan Earnings Response coefficient.

\section{Pendahuluan}

Ekspektasi dari pengumuman laba oleh perusahaan, adalah investor akan bereaksi terhadap informasi laba yang dilaporkan. Pasar yang mengetahui dan meyakini bahwa laba yang dilaporkan memiliki kandungan informasi akan tercermin pada harga saham perusahaan tersebut. Namun, pada Desember 2018 di saat indeks harga saham gabungan (IHSG) turun 3,02\% terdapat beberapa sektor yang mengalami kenaikan harga saham. Tercatat ada 4 sektor yang mengalami kenaikan yaitu sektor industri dasar yang mayoritas diperkuat oleh sub sektor semen beserta sub sektor pulp \& kertas naik sebesar $21,7 \%$, sektor pertambangan naik $8,21 \%$, sektor aneka industri naik 2,78\% dan diikuti oleh sektor keuangan naik $1,82 \%$. Tentunya dengan adanya kenaikan pada sektorsektor tersebut diikuti dengan pertumbuhan kinerja masing-masing emiten (www.koranjakarta.com). Misalnya harga saham sub sektor semen yaitu, PT Semen Indonesia Tbk. (SMGR) yang naik dari Rp. 9.900 menjadi Rp.11.500. Dan harga saham sub sektor pulp \& kertas yaitu, Pabrik Kertas Tjiwi Kimia Tbk. (TKIM) yang naik dari Rp. 2.920 menjadi Rp. 11.100.

Laba yang dihasilkan perusahaan merupakan salah satu informasi yang dapat digunakan sebagai dasar bagi investor di dalam membuat keputusan investasinya, hal ini berarti bahwa saat perusahaan mengumumkan labanya, pasar atau investor akan segera bereaksi terhadap informasi laba yang dilaporkan. Keyakinan pasar atas kandungan informasi laba yang dilaporkan akan tercermin pada harga saham perusahaan tersebut. Namun tinggi / rendahnya laba bukan suatu ukuran mengenai kualitas laba yang dihasilkan perusahaan. Kualitas laba perusahaan dapat diukur dengan koefisien respon laba, yang dapat dipengaruhi oleh berbagai faktor
Persistensi laba menunjukkan kualitas laba yang dihasilkan yang mencerminkan perusahaan tersebut dapat mempertahankan laba operasinya, laba yang persisten dapat meningkatkan kepercayaan investor terhadap kualitas laba perusahaan, yang diharapkan akan memberikan keuntungan (return) yang berkelanjutan bagi investor, hal ini akan tercermin dari respon pasar terhadap informasi laba. Mulyani et al ., (2007) dalam penelitiannya membuktikan bahwa persistensi laba berpengaruh positif terhadap earnings response coefficients, artinya, semakin permanen perubahan laba dari waktu ke waktu maka semakin tinggi tingkat koefisien laba. Berbeda dengan penelitian Imroatussolihah (2013) yang menemukan bahwa persistensi laba tidak berpengaruh secara signifikan terhadap earnings response coefficients.

Pertumbuhan perusahaan dianggap merupakan salah satu variable yang dipertimbangkan para investor, bagaimana perusahaan dalam menginvestasikan dana nya dalam proyek-proyek yang memberikan peluang pertumbuhan perusahaan di masa depan, yang dapat kita ukur dengan menggunakan Investment Opportunity Set (IOS) Investment opportunity set tidak berpengaruh terhadap kualitas laba karena ada kemungkinan tujuan investor dalam berinvestasi bukan untuk mendapatkan keuntungan jangka panjang, melainkan untuk mendapatkan keuntungan jangka pendek berupa capital gain yang diperoleh dari kenaikan harga saham. Nurhanifah \& Jaya (2014) dalam penelitiannya menemukan bahwa, IOS berpengaruh negatif signifikan terhadap earning response coefficient karena mengindikasikan bahwa manajer dari perusahaan yang memiliki IOS tinggi cenderung memanipulasi laba hingga kualitas labanya menjadi rendah, hal ini berbeda dengan hasil penelitian Kurnia \& Sufiyati (2015) IOS tidak memiliki pengaruh terhadap earnings response coefficient. 
Kemampuan perusahaan dalam menghasilkan laba (profitabilitas) merupakan informasi umum digunakan di dalam menilai prosfek investasi, perusahaan dengan profitabilitas yang tinggi cenderung memiliki nilai saham yang tinggi. Mahendra \& Wirama (2017) melakukan penelitian yang menunjukkan bahwa profitabilitas berpengaruh signifikan positif terhadap earnings response coefficients, profitabilitas yang tinggi tersebut dapat menarik para investor untuk berinvestasi. Sementara menurut penelitian Fitri (2013) menyatakan bahwa profitabilitas tidak berpengaruh signifikan terhadap earnings response coefficients.

Leverage rasio menunjukan bagaimana perusahaan melakukan, suatu perusahaan dengan tingkat leverage yang tinggi, mengindikasikan perusahaan melakukan pendanaan dengan utang lebih besar dibandingkan dengan modal sendiri, Pada kasus pendanaan menggunakan utang peningkatan laba perusahaan lebih memberikan manfaat kepada debtholders bukan pemegang saham (Mulyani et al., 2007). Penelitian Imroatussolihah (2013) menunjukkan hasil bahwa leverage berpengaruh negatif terhadap earnings response coefficients, berbeda dengan temuan Delvira \& Nelvirita (2013) yang menyatakan bahwa leverage tidak berpengaruh terhadap earnings response coefficients.

Kepercayaan investor semakin kuat pada perusahaan yang memiliki sumber daya yang besar, yang diproksi dengan ukuran suatu perusahaan. Perusahaan besar mencerminkan kestabilan perusahaan dan mampu menghasilkan laba, sehingga memiliki prospek dimasa depan dibandingkan dengan perusahaan kecil. Dalam penelitian Mulyani et al., (2007) membuktikan bahwa ukuran perusahaan berpengaruh positif terhadap earnings response coefficients, yang menunjukkan bahwa semakin besar ukuran perusahaan, memiliki informasi yang lebih daripada perusahaan kecil sehingga investor akan menggunakan ukuran perusahaan sebagai salah satu faktor yang dapat digunakan dalam pembuatan keputusan investasi. Namun, penelitian Arif (2016) menemukan bahwa ukuran perusahaan tidak berpengaruh signifikan dan memiliki arah yang negatif terhadap earnings response coefficients. Hal ini di karenakan investor menganggap bahwa perusahaan yang besar belum tentu mampu memberikan keuntungan, bisa saja perusahaan tersebut juga memiliki hutang yang besar untuk mendanai kegiatan operasional perusahaan.

Berdasarkan latar belakang masalah tersebut, pada kesempatan ini penulis tertarik untuk melakukan penelitian terkait faktor-faktor yang mempengaruhi kualitas laba suatu perusahaan terhadap reaksi pasar. Faktor-faktor yang akan diteliti pada penelitian ini yaitu persistensi laba, peluang bertumbuh, profitabilitas, leverage dan ukuran perusahaan terhadap sebuah koefisien yang mengukur hubungan antara reaksi pasar terhadap informasi laba yang dilaporkan oleh suatu entitas. Untuk mengetahui kandungan informasi dalam laba dapat menggunakan Earnings Response Coefficient (ERC). Kuatnya reaksi pasar terhadap informasi laba yang tercermin dari tingginya ERC, menunjukkan laba yang dilaporkan berkualitas. Demikian sebaliknya, lemahnya reaksi pasar terhadap informasi laba yang tercermin dari rendahnya ERC, menunjukkan laba yang dilaporkan kurang atau tidak berkualitas (Boediono, 2005).

Dasar penelitian earnings response coefficients adalah respon pasar terhadap suatu kandungan informasi laba akuntansi yang berbeda-beda pada setiap perusahaan. Reaksi pasar akan bergantung pada kredibilitas dan kualitas informasi dari laba tersebut. Berdasarkan fenomena di atas maka peneliti tertarik untuk melakukan penelitian dengan judul "Respon Investor atas sinyal, peluang Pertumbuhan, Struktur Modal, dan Ukuran Perusahaan Pada Perusahaan Manufaktur di BEI periode 2014-2018."

\section{Tujuan Penelitian.}

Adapun tujuan penelitiannya adalah untuk mengetahui pengaruh persistensi laba, peluang bertumbuh, struktur modal, profitabilitas dan ukuran perusahaan terhadap earnings response coefficient. 


\section{Landasan Teoritis.}

Teori sinyal pertama kali dikembangkan oleh (Ross, 1977) yang menyatakan bahwa pihak eksekutif perusahaan memiliki informasi lebih baik mengenai perusahaannya akan terdorong untuk menyampaikan informasi tersebut kepada calon investor agar harga saham perusahaannya meningkat. Penman \& Zhang (2006) menjelaskan laporan laba yang memberikan signal merupakan laba yang tumbuh stabil (sustainable). Sustainable earnings adalah laba yang mempunyai kualitas tinggi dan sebagai indikator future earnings. Jika suatu perusahaan memperoleh laba yang tinggi maka pihak yang berkepentingan akan memperoleh keuntungan. Oleh karena itu dengan adanya signal yang dilakukan perusahaan mengenai informasi kondisi perusahaan akan memberikan respon pada reaksi pasar yang beragam dan berguna juga bagi kepentingan perusahaan dalam memenuhi modal dalam usaha.

Wernerfelt (1984) menjelaskan bahwa menurut pandangan Resource Based Theory perusahaan memperoleh keunggulan kompetitif dan kinerja keuangan yang baik dengan cara memiliki, menguasai, dan memanfaatkan aset-aset strategis yang penting, termasuk aset berwujud maupun aset tidak berwujud. Menurut Barney (1991), terdapat empat kriteria sumber daya sebuah perusahaan untuk mencapai keunggulan kompetitif yang berkelanjutan yaitu :

(a) Sumber daya harus menambah nilai positif bagi perusahaan.

(b) Sumber daya harus bersifat unik atau langka di antara calon pesaing dan pesaing yang ada sekarang ini.

(c) Sumber daya harus sukar ditiru.

(d) Sumber daya tidak dapat digantikan dengan sumber lainnya oleh perusahaan pesaing.

Ketika suatu perusahaan memiliki keuanggulan kompetitif dan kinerja keuangan yang baik untuk bersaing dengan perusahaan lainnya, perusahaan tersebut berpotensi menghasilkan laba yang tinggi / laba yang sesuai dengan harapan. Sehingga perusahaan yang memenuhi kriteria Barney (1991) lebih menarik minat pasar / investor untuk melakukan investasi.
Jensen \& Meckling (1976) mendefinisikan hubungan keagenan sebagai suatu kontrak di mana satu orang atau lebih pemilik perusahaan (principal) berhubungan dengan orang lain atau manager (agent) untuk melakukan tugas tertentu atas nama perusahaan yang melibatkan pendelegasian beberapa pengambilan keputusan otoritas kepada agent. Teori keagenan menggambarkan hubungan antara pemilik atau pemegang saham (principal) dengan manager (agent) yang disebut sebagai agency relationship (Ross, 1973). Teori keagenan menggambarkan perusahaan sebagai serangkaian kontrak. Salah satu kontrak yang utama adalah kontrak antara pemilik perusahaan sebagai principal dengan pihak manajemen sebagai agent. Pemilik menyerahkan tugas mengelola perusahaan kepada pihak yang lebih ahli untuk menjalankan perusahaan, yaitu pihak manajemen. Masalah keagenan muncul akibat agent tidak memaksimumkan kesejahteraan prinsipal (Ross, 1973). Misalnya, agen dalam hal ini mempunyai wewenang dalam mengelola dan menggunakan fasilitas yang dipercayakan oleh pemegang saham. Di lain pihak investor dan kreditur mengacu pada laba perusahaan tetapi karena adanya perbedaan kepentingan (conflict interest) antara agen dan prinsipal, maka agen pasti akan bersifat oportunis yang menguntungkan bagi agen. Akibatnya kualitas laba menjadi rendah, laba tersebut akan diragukan oleh pengguna informasi (investor / kreditur) jika laba yang disampaikan tidak sesuai dengan fakta yang ada sehingga menyebabkan investor dan kreditur bisa salah dalam mengambil keputusan investasi.

\section{Kerangka Pemikiran.}

\section{Pengaruh Persistensi Laba Terhadap Earnings Respose Coefficient}

Persistensi laba merupakan suatu ukuran yang menjelaskan kemampuan perusahaan untuk mempertahankan jumlah laba yang diperoleh saat ini sampai masa mendatang. Persistensi laba ini juga menunjukkan bahwa laba yang diperoleh perusahaan tetap dan bukan karena suatu peristiwa tertentu (transitory) seperti penjualan aset. Signaling theory menunjukkan persistensi laba dapat menjadi sinyal yang positif 
untuk koefisien respon laba karena, jika laba perusahaan lebih persisten dapat meningkatkan kepercayaan investor terhadap kualitas laba perusahaan yang diharapkan akan memberikan keuntungan (return) yang berkelanjutan bagi investor. Oleh karena itu, dapat diperkirakan di masa yang akan datang kualitas laba akan semakin baik dan nilai ERC akan semakin tinggi. Persistensi laba memiliki hubungan yang positif terhadap earnings response coefficient di karenakan persistensi laba mencerminkan kualitas laba perusahaan. Hasil penelitian Mulyani et al. (2007), dan Delvira \& Nelvirita (2013) membuktikan bahwa persistensi laba berpengaruh positif terhadap earnings response coefficient (ERC).

\section{H1 : Persistensi laba berpengaruh positif terhadap earnings response coefficient}

\section{Pengaruh Peluang Pertumbuhan Terhadap Earnings Response Coefficient}

Peluang pertumbuhan mengindikasikan kemampuan perusahaan dalam mempertahankan kelangsungan usaha. Perusahaan yang memiliki kesempatan bertumbuh akan menarik minat investor karena berpeluang untuk mengasilkan return yang optimal di masa yang akan datang. Investment opportunity set (IOS) menggambarkan tentang luasnya kesempatan atau peluang investasi bagi suatu perusahaan. Berdasarkan signaling theory, IOS dapat menjadi sinyal positif untuk para investor karena, perusahaan dengan investment opportunity set yang tinggi cenderung dinilai positif oleh investor karena lebih memiliki prospek yang baik untuk keuntungan di masa yang akan datang. Sehingga, investor tertarik untuk melakukan investasi pada perusahaan yang memiliki IOS yang tinggi. Oleh karena itu, Investment opportunity set (IOS) menunjukkan pengaruh positif terhadap earnings response coefficient (ERC). Hasil penelitian Novianti (2012) membuktikan bahwa investment opportunity set (IOS) berpengaruh positif terhadap earnings response coefficient (ERC).

Tetapi berdasarkan teori keagenan, nilai IOS yang tinggi juga dapat mengindikasikan adanya tindakan manipulasi laba oleh manajer perusahaan (agent) sehingga kualitas labanya (ERC) akan manjadi rendah. Oleh sebab itu, investor menjadi tidak tertarik dengan perusahaan yang melakukan tindakan manipulasi dan akan dinilai tidak menguntungkan bagi investor (principal). Jadi, Investment opportunity set (IOS) menunjukkan pegaruh negatif terhadap earnings response coefficient (ERC). Hasil penelitian Nurhanifah \& Jaya (2014) membuktikan bahwa investment opportunity set (IOS) berpengaruh negatif terhadap earnings response coefficient (ERC).

H2 : Peluang bertumbuh berpengaruh terhadap earnings response coefficient

\section{Pengaruh Profitabilitas Terhadap Earnings Response Coefficient}

Profitabilitas merupakan kemampuan perusahaan menghasilkan laba selama periode tertentu dengan menggunakan aktiva yang produktif atau modal. Semakin tinggi tingkat profitabilitas perusahaan, maka hal ini menggambarkan bahwa perusahaan tersebut semakin berhasil mengelola aktiva atau modal yang dimilikinya untuk menciptakan laba. Perusahaan yang memiliki profitabilitas tinggi memiliki kemampuan yang lebih untuk memberikan return kepada investor. Berdasarkan teori signaling perusahaan yang memiliki kemampuan untuk memberikan return tinggi memiliki sinyal yang kuat dalam menarik minat investor untuk melakukan investasi. Oleh karena itu, profitabilitas menunjukkan pengaruh positif terhadap earnings response coefficient (ERC). Hasil penelitian Mahendra \& Wirama (2017), dan Hasanzade et al. (2013) membuktikan bahwa profitabilitas berpengaruh positif terhadap earnings response coefficient (ERC).

\section{H3 : Profitabilitas berpengaruh positif terhadap earnings response coefficient}

\section{Pengaruh Struktur Modal Terhadap Earnings Response Coefficient \\ Struktur modal (Leverage) menunjukkan besarnya aset perusahaan yang dibiayai oleh hutang. Perusahaan yang memiliki jumlah hutang yang lebih besar mencerminkan resiko}


yang lebih besar pula. Karena, jika perusahaan memiliki hutang dalam jumlah besar dapat menimbulkan resiko seperti gagal bayar sampai kebangkrutan perusahaan. Signaling theory juga menunjukkan bahwa leverage memberikan sinyal untuk para investor dalam rangka pengambilan keputusan investasi dalam suatu perusahaan. Untuk perusahaan dengan utang yang banyak, jika terjadi peningkatan laba maka hal tersebut menguntungkan debtholder daripada investor. Oleh karena itu, leverage dapat menunjukkan sinyal yang negatif terhadap koefisien respon laba , karena investor berpendapat bahwa laba tersebut hanya menguntungkan pihak debtholder. Jadi, Leverage menunjukkan pengaruh negatif terhadap eanings response coefficient (ERC). Hasil penelitian Mulyani et al. (2007), Suhartono (2015), Tiolemba \& Ekawati (2008), Imroatussolihah (2013) membuktikan bahwa leverage berpengaruh negatif terhadap earnings response coefficient (ERC).

H4 : Struktur modal berpengaruh negatif terhadap earnings response coefficient

\section{Pengaruh Ukuran Perusahaan Terhadap Earnings Respose Coefficient}

Ukuran perusahaan menunjukkan besar kecilnya suatu perusahaan. Ukuran perusahaan berpengaruh terhadap ERC karena semakin besar ukuran perusahaan maka semakin besar aktivitas bisnis, sumber daya, unit bisnis, karyawan, modal dan pendapatan suatu perusahaan. Berdasarkan resource-based theory, perusahaan yang besar juga dianggap mampu mengelola sumber dayanya dengan baik sehingga memiliki keunggulan kompetitif dan dapat meningkatkan kinerjanya untuk dapat bersaing dengan perusahaan lainnya. Sehingga, perusahaan yang memiliki keunggulan kompetitif tersebut mampu menghasilkan kualitas laba (ERC) yang baik dan menarik minat investor. Jadi, Ukuran perusahaan memiliki pengaruh yang positif terhadap earnings response coefficient (ERC). Hasil penelitian Syafrina (2017), Mulyani et al. (2007), Sandi (2013), dan Mashayekhi \& Aghel (2016) membuktikan bahwa ukuran perusahaan berpengaruh positif terhadap earnings response coefficient ( ERC).

H5 : Ukuran perusahaan berpengaruh positif terhadap earnings response coefficient

Kerangka Pemikiran

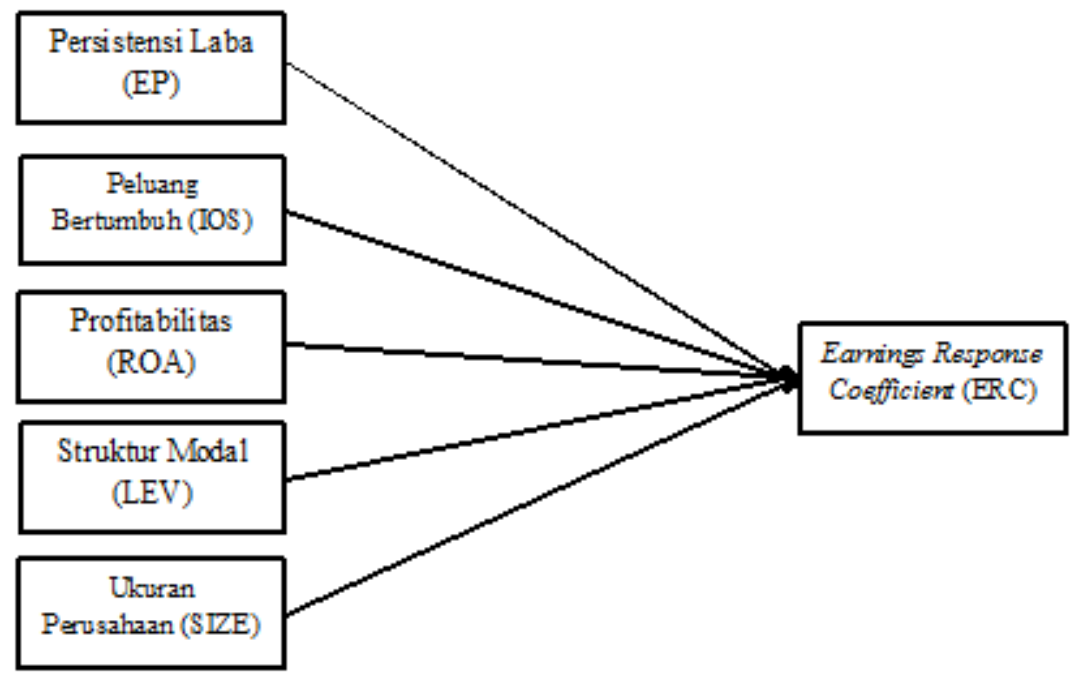


Populasi dan Sampel.

Dalam penelitian ini, penulis akan menggunakan perusahaan-perusahaan manufaktur yang terdaftar di Bursa Efek Indonesia (BEI) pada periode 2014-2018 sebagai objek penelitian. Data yang digunakan dalam penelitian ini adalah data sekunder yang diperoleh dari laporan keuangan tahunan dan

harga saham penutupan perusahaan manufaktur yang terdaftar di Bursa Efek Indonesia (BEI) pada periode 2014-2018 yang telah dipublikasikan.

Populasi yang diteliti adalah semua perusahaan manufaktur yang terdaftar di Bursa Efek Indonesia periode 2014-2018. Pengambilan sampel dalam penelitian ini menggunakan nonprobabilistic sampling yaitu purposive sampling, yaitu pengambilan sampel berdasarkan kriteria tertentu.

Kriteria yang ditetapkan dalam pengambilan sampel penelitian ini adalah:

1. Perusahaan Manufaktur yang terdaftar di BEI periode 2014-2018.

2. Perusahaan yang tidak baru IPO, relisting, atau delisting selama periode 2014-2018.

3. Perusahaan yang menerbitkan laporan keuangan akhir tahun yang telah diaudit selama periode 2014-2018.

4. Perusahaan yang menyajikan laporan keuangannya dalam bentuk mata uang Rupiah (Rp.).

5. Perusahaan yang tidak mengalami kerugian selama periode 2014-2018.

6. Penyajian laporan keuangan perusahaan yang memiliki data-data yang dibutuhkan peneliti.

\section{Kriteria Pengambilan Sampel}

\begin{tabular}{|l|l|c|}
\hline No & \multicolumn{1}{|c|}{ Kriteria } & Jumlah \\
\hline 1 & $\begin{array}{l}\text { Perusahaan Manufaktur yang terdaftar di Bursa Efek } \\
\text { Indonesia Periode 2014-2018 }\end{array}$ & 147 \\
\hline 2 & $\begin{array}{l}\text { Perusahaan yang baru IPO, relisting, atau delisting } \\
\text { selama periode 2014-2018 }\end{array}$ & 19 \\
\hline 3 & $\begin{array}{l}\text { Perusahaan yang tidak menerbitkan laporan } \\
\text { keuangan audited akhir tahun selama periode 2014- } \\
2018\end{array}$ & 27 \\
\hline 4 & $\begin{array}{l}\text { Perusahaan yang menerbitkan laporan keuangannya } \\
\text { tidak dalam bentuk mata uang rupiah (Rp.) }\end{array}$ & 29 \\
\hline 5. & $\begin{array}{l}\text { Perusahaan yang mengalami kerugian selama } \\
\text { periode 2014-2018 }\end{array}$ & 32 \\
\hline 6. & $\begin{array}{l}\text { Perusahaan yang tidak memiliki kelengkapan data } \\
\text { yang dibutuhkan. }\end{array}$ & 9 \\
\hline & Sampel yang diambil per tahun & 31 \\
\hline & Sampel yang diambil dalam penelitian & 155 \\
\hline
\end{tabular}

\section{Variabel Penelitian.}

\section{Variabel Dependen}

\section{a. Earnings Response Coefficients}

Earnings Response Coefficients (ERC) adalah reaksi atas laba yang diumumkan oleh perusahaan. ERC merupakan koefisien $\alpha \_1$ pada hubungan Cummulative Abnormal Return (CAR) dan Unexpected Earnings (UE) setelah dikendalikan oleh Return Tahunan (RT) (Setiati \& Kusuma, 2004) (Jaswadi, 2004).

Nilai ERC $\left(\alpha \_1\right)$ didapatkan dengan bantuan SPSS 20. Dalam hal ini penulis hanya ingin mencari nilai $\alpha \_1$ dan bukan menguji suatu model regresi, maka signifikansi dari model 
regresi tersebut dapat diabaikan dan hanya dependen (ERC). Rumusnya adalah: mengambil koefisien $\alpha \_1$ untuk menjadi variabel

$C A R_{i t}=\alpha_{o}+\alpha_{1} U E_{i t}+\alpha_{2} R_{i t}+\varepsilon_{i t}$

$C A R_{\text {it }}=$ CAR perusahaan i selama perioda jendela \pm 5 hari dari publikasi laporan keuangan

$\alpha_{1} \quad=$ Nilai Earnings Response Coefficients (ERC)

$U E_{i t}=$ Unexpected Earnings perusahaan $i$ pada periode (tahunan) $t$

$R_{i t} \quad=$ Return Tahunan perusahan $i$ pada periode (tahunan)

$\varepsilon_{i t} \quad=$ komponen error dalam model atas perusahaan i pada periode $\mathrm{t}$

Untuk mencari nilai Earnings Response Coefficients (ERC) atau $\alpha_{1}$ dengan menggunakan rumus 3.1 , perlu dicari terlebih dahulu nilai Cummulative Abnormal Return (CAR), Unexpected Earnings (UE), dan Return Tahunan (RT)

(1) Cummulative Abnormal Return (CAR)

Return abnormal dihitung dengan menggunakan model sesuaian pasar (market-adjusted model), yang mengacu pada penelitian (Jaswadi, 2004).

$$
C A R_{i t}(-5+5)=\sum_{t=-5}^{t=+5} A R i t
$$

Return abnormal kumulatif (Cummulative Abnormal Return disingkat CAR) pada saat laporan keuangan dipublikasi dihitung dengan metode studi peristiwa, yang menggunakan periode lima hari sebelum (-5) dan lima hari sesudah (+5) tanggal publikasi laporan keuangan.

Perhitungannya adalah sebagai berikut :

Keterangan:

$C A R_{i t}(-5+5)=$ CAR perusahaan $i$ selama periode jendela \pm 5 hari dari tanggal publikasi laporan keuangan

$A R_{i t} \quad=$ abnormal return perusahaan $i$ pada hari $t$

$R_{i t} \quad=$ return sesungguhnya perusahaan $i$ pada hari $t$

$R m_{i t} \quad=$ return pasar pada hari $t$

Rumus untuk menghitung return individu dan return pasar :

(a) Actual Return (return individu)

$R_{i t}=\frac{P_{i t}-P_{i t}-1}{P_{i t}-1}$

Keterangan:

$R_{i t} \quad=$ Return individu sesungguhnya perusahaan $i$ pada hari $t$

$P_{i t} \quad=$ Harga saham penutupan perusahaan $i$ pada hari $t$

$P_{i t}-1=$ Harga saham penutupan perusahaan $i$ pada hari $t-1$

(b) Return Pasar

$R M_{t}=\frac{\mathrm{IHSG}_{t}-I H S G_{t-1}}{I H S G_{t-1}}$

Keterangan:

$R M_{t} \quad=$ Return pasar pada periode (hari) $t$

$\mathrm{IHSG}_{t}=$ Indeks Harga Saham Gabungan pada hari $t$

$I H S G_{t-1}=$ Indeks Harga Saham Gabungan pada hari sebelum $t$

\section{(2) Unexpected Earnings (UE)}

Unexpected Earnings merupakan selisih antara laba akuntansi yang direalisasi dengan laba akuntansi yang diekspektasi oleh pasar. Dalam hal ini, Earnings akan diukur dengan Earnings before extraordinary items. Dalam penelitian ini, Unexpected Earnings dihitung dengan menggunakan model random walk, seperti yang 
dilakukan oleh Suaryana (2005), Diantimala (2008) dan Mulyani et al. (2007), Rumusnya

$$
U E_{i t}=\frac{\left(E A T_{i t}-E A T_{i t-1}\right)}{\left|E A T_{i t-1}\right|}
$$

adalah:

Keterangan:

$U E_{i t} \quad=$ unexpected EAT perusahaan $i$ pada periode $t$

$E A T_{i t}=$ EAT perusahaan $i$ pada periode $t$

$E A T_{i t-1}=$ EAT perusahaan $i$ pada periode $t-1$

\section{(3) Return Tahunan (RT)}

Variabel return tahunan ini merupakan variabel tambahan (variabel kontrol) yang bertujuan untuk mengantisipasi bias pengukuran yang ada $R T_{i t}=\frac{P_{i t}-P_{i t-1}}{P_{i t-1}}$

Keterangan :

$\mathrm{RT}_{\mathrm{it}} \quad=$ return tahunan perusahaan pada perusahaan $i$ pada periode (tahun) $t$

$\mathrm{P}_{\mathrm{it}} \quad=$ closing price perusahaan $i$ pada periode (tahun) $t$

$\mathrm{P}_{\mathrm{it}-1}=$ closing price untuk perusahaan $i$ pada perusahaan (tahun) sebelum $t$

\section{Variabel Independen}

\section{a. Persistensi Laba}

Persistensi laba adalah kemampuan suatu perusahaan untuk mempertahankan nilai labanya yang dapat diukur dengan regresi atas perbedaan $X_{i t}=\alpha+\beta X_{i t-1}+\varepsilon_{1}$

Keterangan :

$X_{i t} \quad=$ Laba perusahaan i pada tahun $\mathrm{t}$

$X_{i t-1}=$ Laba perusahaan i pada tahun $\mathrm{t}-1$

$\beta=$ Koefisien hasil regresi (persistensi laba)

\section{b. Peluang Pertumbuhan (IOS)}

Peluang pertumbuhan yang diproksikan dengan Investment Opportunity Set ( IOS) yang dapat pada penggunaan metode studi peristiwa yang menggunakan jendela periode panjang (Jaswadi, 2004). Variabel return tahunan dirumuskan sebagai berikut : laba sekarang dengan laba sebelumnya (Chandrarin dalam Mulyani et al., 2007), (Jaswadi, 2004). Kemudian persistensi laba pertahun akan dicari rata-ratanya. Persistensi laba dapat dihitung menggunakan rumus : 
dihasilkan. Rumus return on asset (ROA)

$R O A=\frac{E A T}{\text { Total Assets }}$

Keterangan :

ROA $\quad=$ Return on assets

EAT $\quad=$ Laba perusahaan setelah pajak

Total Assets $\quad=$ Total aset perusahaan $\mathrm{i}$

d. Struktur Modal (Leverage)

Struktur permodalan yang diproksikan dengan

leverage adalah rasio total hutang dengan total

Leverage $=\frac{\text { Total Debt }}{\text { Total Asset }}$

Keterangan :

Total Debt = Total utang perusahaan i periode $\mathrm{t}$

Total Asset = Total aktiva perusahaan i periode $\mathrm{t}$

Kemudian besarnya leverage setiap tahun untuk masing-masing perusahaan dicari rata-ratanya.

e. Ukuran Perusahaan

Ukuran perusahaan adalah ukuran besar atau kecilnya suatu perusahaan yang diukur dengan

SIZE $=$ Ln $($ Total Asset $)$

Keterangan :

Total Asset = Total aktiva perusahaan i periode $\mathrm{t}$

\section{Hasil Penelitian.}

\section{Uji Statistika Deskriptif}

Hasil pada tabel statistik terdapat 31 sampel yang digunakan dalam penelitian ini yang menunjukkan bahwa :

a. Variabel Earnings Response Coefficients (ERC) menggambarkan respon pasar terhadap informasi laba yang diumumkan oleh suatu perusahaan. Respon pasar terendah dimiliki $-0,5947$ yaitu PT. Unilever Indonesia Tbk. dan Respon pasar tertinggi 0.9007 PT. Kimia Farma Tbk. Rata-rata respon pasar terhadap informasi laba sebesar 0,049835, dengan standar deviasi sebesar 0,2429032. Yang menunjukkan bahwa penyebaran data semakin tidak bervariasi atau seragam dan sebagian besar perusahaan sampel memiliki respon pasar yang rendah pada saat pengumuman informasi laba. rata-ratanya. yang akan datang adalah sebesar 39,97\%. dihitung menggunakan rumus :

aktiva perusahaan (Harahap, 2004). Struktur modal atau leverage dapat dihitung dengan menggunakan rumus : nilai logaritma dari total aset (Harahap, 2004). Ukuran perusahaan dihitung menggunakan data laporan keuangan perusahaan kemudian dihitung

b. Variabel Persistensi Laba (PL) yang diukur dengan regresi perbedaan laba sekarang dengan laba tahun sebelumnya menunjukkan bahwa, data amatan yang berpotensi penurunan laba sebesar $-0,4554$ adalah PT. Akasha Wira International Tbk, dan data perusahaan yang berpotensi untuk mempertahankan labanya dari tahun ke tahun dengan nilai 1.9738 adalah PT. Unilever Indonesia Tbk. Rata-rata dari persistensi laba sebesar 0,399706 dan standar deviasinya sebesar 0,5358129 . Hasil dari nilai rata-rata yang kecil dan standar deviasi yang mendekati rata-rata menunjukkan bahwa penyebaran data semakin tidak bervariasi atau seragam dan sebagian besar perusahaan sampel tidak memiliki laba yang persisten. Nilai ratarata 0,399706 menunjukkan bahwa rata-rata kemampuan perusahaan untuk mempertahankan jumlah laba yang diperoleh saat ini sampai masa 
c. Variabel Peluang Pertumbuhan (IOS) yang diukur dengan market value to book value of asset (MVBVA) data perusahaan yang memiliki peluang pertumbuhan terendah sebesar 0,4815, yaitu PT. Intan Wijaya International Tbk, sedangkan data perusahaan yang memiliki peluang pertumbuhan tertinggi sebesar 19,3208, yaitu PT. Unilever. Rata-rata dari peluang pertumbuhan sebesar 2,923194 dengan standar deviasi sebesar 4,0703967. Hasil dari nilai ratarata yang kecil dan standar deviasi yang lebih besar dari nilai rata-rata menunjukkan bahwa penyebaran data beragam dan nilai rata-rata menunjukkan bahwa rata-rata peluang pertumbuhan perusahaan dalam penelitian ini dimasa mendatang adalah $292,31 \%$.

d. Variabel Profitabilitas (ROA) yang diukur menggunakan return on assets menunjukkan data perusahaan dengan tingkat pengembalian laba terendah dengan nilai ROA 0,0015 yaitu PT. Nusantara Inti Corpora, sedangkan data perusahaan dengan tingkat pengembalian aset yang paling produktif 0,4012 yaitu PT. Unilever Indonesia Tbk. Rata-rata profitabilitas data amatan sebesar 0,103858 dengan standar deviasinya sebesar 0,1003057 . Hasil dari nilai rata-rata yang kecil dan standar deviasi yang mendekati rata-rata menunjukkan bahwa penyebaran data semakin tidak bervariasi atau seragam. Nilai rata-rata sebesar 0,103858 menunjukkan bahwa rata-rata nilai aset perusahaan sampel yang dapat menghasilkan laba bersih hanya sebesar 10,38\%

e. Variabel Struktur Modal (LEV) yang diukur dengan menggunakan debt to asset ratio (DAR) menunjukkan bahwa data perusahaan yang memiliki aset yang dibiayai oleh hutang terkecil 0,1129, yaitu PT. Intan Wijaya International Tbk, dan perusahaan yang sebagian besar aset nya dibiayai oleh hutang sebesar 0,6836 yaitu PT. Unilever Indonesia Tbk. Ratarata dari struktur modal sebesar 0,390966 dengan standar deviasinya sebesar 0,1640780 . Hasil dari nilai rata-rata yang kecil dan standar deviasi yang mendekati rata-rata menunjukkan bahwa penyebaran data semakin tidak bervariasi atau seragam. Nilai rata-rata sebesar 0,390966 menunjukkan bahwa $39,09 \%$ kekayaan perusahaan sampel dibiayai oleh liabilitas perusahaan.

f. Variabel Ukuran Perusahaan (SIZE) yang mengukur besarnya suatu perusahaan dari aset yang dimiliki menunjukkan data perusahaan terkecil dalam sampel sebesar 26,2054, yaitu PT. Intan Wijaya International Tbk, sedangkan data perusahaan terbesar 33.2445 adalah PT. Astra International Tbk. Rata-rata data ukuran perusahaan adalah sebesar 28,785539 dan standar deviasinya sebesar 1,7733739 . Hasil dari nilai standar deviasi yang menjauhi rata-rata menunjukkan bahwa penyebaran data bervariasi. Nilai rata-rata sebesar 28,785539 menunjukkan bahwa terdapat 12 perusahaan sampel yang dianggap perusahaan berskala besar karena 12 perusahaan tersebut memiliki SIZE diatas ratarata. Sementara, 19 perusahaan lainnya merupakan perusahaan berskala kecil karena SIZE nya berada dibawah rata-rata.

\section{Analisis Regresi Berganda}

Nilai konstanta yang terdapat pada analisis regresi berganda adalah sebesar 0,895 yang berarti nilai ERC akan sebesar 0,895 jika kondisi semua variabel independen bernilai nol. Model regresi dalam penelitian ini adalah sebagai berikut : ERC $=0,632+0,194$ PL - 0,042IOS +
0,104LEV + 0,106ROA - 0,021SIZE

\section{Uji Asumsi Klasik}

\section{a. Uji Normalitas}

Uji normalitas bertujuan untuk menguji apakah dalam model regresi, variabel residual memiliki distribusi normal. Uji normalitas dilakukan dengan One-Sample Kolmogrov Smirnov Test. Dari hasil pada tabel 4.3 menunjukkan nilai Asymp.Sig (2-Tailed) adalah sebesar 0,649. Nilai 0,649 lebih besar dari $\alpha(0,05)$ maka tidak tolak Ho dan dapat disimpulkan bahwa data yang diteliti berdistribusi normal.

\section{b. Uji Heteroskedastisitas}

Uji heteroskedastisitas bertujuan untuk menguji apakah dalam model regresi terjadi ketidaksamaan variance dari residual satu pengamatan ke pengamatan yang lain. Uji heteroskedastisitas dilakukan dengan uji glejser. 
Berdasarkan tabel uji heteroskedastisitas nilai Sig. > 0,05 yang berarti tidak tolak Ho atau dapat disimpulkan bahwa model regresi tidak terjadi heteroskedastisitas.

\section{c. Uji Multikolinearitas}

Uji Multikolinearitas bertujuan untuk menguji apakah didalam model regresi terdapat adanya korelasi antar variabel bebas. Pada tabel uji multikolinieritas dapat dilihat nilai Variance Inflation Factor (VIF) tidak ada yang melebihi nilai 10 (VIF < 10) dan nilai tolerance tidak ada yang kurang dari 0,1 (Tolerance $>0,10$ ). Dari hasil pada tabel tersebut dapat disimpulkan bahwa tidak terjadi multikolinearitas dalam model regresi ini.

\section{d. Uji Autokorelasi}

Uji autokorelasi bertujuan untuk menguji apakah terdapat korelasi antara kesalahan pengganggu pada periode $t$ dengan kesalahan pengganggu pada periode $\mathrm{t}-1$ pada model regresi linear. Uji autokrelasi ini menggunakan Run Test. Dapat dilihat dalam tabel Run Test angka Asymp.Sig (2-Tailed) sebesar 0,068 > 0,05 ( $\alpha=$ $5 \%$ ). Maka dapat disimpulkan bahwa didalam model penlitian ini tidak terjadi autokorelasi.

\section{Uji Keberartian Model (Uji F)}

Pengujian ini digunakan untuk mengetahui apakah model regresi dapat digunakan untuk memprediksi variabel dependenya atau tidak. Setelah melakukan uji F menggunakan ANOVA dengan SPSS 20. Berdasarkan tabel ANOVA dapat dilihat nilai Sig. 0,028 $<0,05$ yang berarti tolak Ho atau model regresi dapat digunakan untuk memprediksi earnings response coefficient.

\section{Uji Koefisien Regresi Parsial (Uji t)}

Uji koefisien regresi parsial digunakan untuk menunjukkan seberapa jauh satu variabel independen secara individual dalam menerangkan variabel dependen (ERC). Dari hasil uji pada tabel uji-t diperoleh tingkat signifikansi dari setiap variabel independen. Untuk menginterpretasikan koefisien variabel independen, dapat dilihat pada unstandardized coefficients.

a. Koefisien regresi untuk persistensi laba (PL) adalah 0,194 dengan nilai Sig. sebesar $0,015(0,030 / 2)<\alpha=5 \%$ maka tolak Ho

b. Koefisien regresi untuk peluang pertumbuhan (IOS) adalah -0,042 dengan nilai Sig. sebesar $0,016(0,032 / 2)>\alpha=$ $5 \%$ maka tolak Ho

c. Koefisien regresi untuk struktur modal (LEV) adalah 0,104 dengan nilai Sig. sebesar $0,339(0,678 / 2)>\alpha=5 \%$ maka tidak tolak Ho

d. Koefisien regresi untuk profitabilitas (ROA) adalah 0,106 dengan nilai Sig. sebesar $0,442(0,884 / 2)>\alpha=5 \%$ maka tidak tolak Ho

e. Koefisien regresi untuk ukuran perusahaan (SIZE) adalah -0,021 dengan nilai Sig. sebesar $0,194(0,388 / 2)<\alpha=5 \%$ maka tidak tolak Ho.

\section{Uji Ketepatan Perkiraan}

Uji ketepatan perkiraan ini bertujuan untuk mengukur seberapa jauh kemampuan model dalam menerangkan variasi variabel independen. Berdasarkan tabel $R^{2}$, nilai adjusted $\mathrm{R}$ Square menunjukkan angka 0,253 . Hal ini mengindikasikan bahwa pengaruh variabel independen yang terdiri dari persistensi laba, peluang pertumbuhan, struktur modal, profitabilitas dan ukuran perusahaan terhadap variabel dependennya (ERC) sebesar 25,3\% sedangkan $74,7 \%$ ditentukan oleh faktor-faktor lain diluar variabel penelitian.

\section{Pembahasan.}

\section{Pengaruh Persistensi Laba terhadap ERC.}

Dari hasil uji t, dapat disimpulkan tolak Ho yang berarti terdapat cukup bukti persistensi laba berpengaruh secara signifikan dengan arah yang positif terhadap earnings response coefficient. Hal ini membuktikan bahwa informasi laba merupakan sinyal yang positif yang direspon oleh pasar, dilihat dari koefisien respon laba, perusahaan dengan laba yang lebih persisten dapat meningkatkan kepercayaan investor terhadap kualitas laba perusahaan yang diharapkan akan memberikan pengembalian (return) yang berkelanjutan bagi investor, 
sehingga perusahaan dengan laba yang persisten lebih menarik minat investor.

Hasil penelitian ini didukung dengan hasil penelitian Mulyani et al. (2007) dan Delvira \& Nelvirita (2013) yang menyatakan bahwa persistensi laba berpengaruh signifikan dan memberikan arah yang positif terhadap earnings response coefficient (ERC). Pengaruh Peluang Pertumbuhan terhadap ERC

\section{Pengaruh Peluang Pertumbuhan terhadap ERC}

Dari hasil uji t dapat disimpulakan tolak Ho atau terdapat cukup bukti peluang pertumbuhan berpengaruh secara signifikan dengan arah yang negatif terhadap earnings response coefficient. Hal ini menunjukan nilai IOS yang tinggi juga mengindikasikan adanya tindakan manipulasi laba oleh manajer perusahaan (agent) sehingga kualitas labanya (ERC) akan manjadi rendah. Oleh sebab itu, investor menjadi tidak tertarik dengan perusahaan yang melakukan tindakan manipulasi dan akan dinilai tidak menguntungkan bagi investor (principal).

Hasil penelitian ini sesuai dengan penelitian yang dilakukan oleh Nurhanifah \& Jaya (2014) yang menyatakan bahwa investment opportunity set berpengaruh negatif terhadap earnings response coefficient. Pengaruh Struktur Modal terhadap ERC.

\section{Pengaruh Struktur Modal terhadap ERC}

Dari hasil uji t dapat disimpulkan tidak tolak Ho atau tidak terdapat cukup bukti struktur modal berpengaruh secara signifikan terhadap earnings response coefficient. Hal ini menunjukkan leverage bukan merupakan fokus utama investor dalam membuat keputusan investasi. Melainkan, para investor lebih melihat besarnya angka laba pada perusahaan yang mampu mempertahankan labanya setiap tahun. Selain itu, perusahaan yang memiliki nilai leverage yang tinggi juga mengindikasikan tingginya tingkat kepercayaan debtholder kepada perusahaan. Semakin tinggi nilai hutang maka debtholder semakin dipercaya perusahaan tersebut mampu mengembalikan hutangnya. Kepercayaan debtholder ini menggambarkan bahwa perusahaan dapat mengelola hutangnya dengan baik dan dengan adanya hutang tersebut dapat meningkatkan kinerja perusahaan. Sehingga pasar dapat bereaksi positif terhadap perusahaan dengan nilai leverage yang tinggi.

\section{Pengaruh Profitabilitas terhadap ERC}

Dari hasil uji t, disimpulkan tidak tolak Ho atau tidak terdapat cukup bukti profitabilitas berpengaruh secara signifikan terhadap earnings response coefficient. Hal ini menunjukkan bahwa ROA bukanlah faktor dipertimbangkan oleh investor dalam pengambilan keputusan. Investor kurang peduli atas profitabilitas yang diukur dengan ROA, karena ROA memperlihatkan tingkat pengembalian atas aset yang dimiliki oleh perusahaan (jangka panjang). Sehingga terdapat kemungkinan bahwa investor yang ada dalam penelitian bukanlah investor yang rasional, atau investor jangka pendek yang hanya berorientasi pada capital gain sehingga tidak tertarik pada kekmapuan perusahaan menghasilkan laba yang di proksi dengan ROA.

\section{Pengaruh Ukuran Perusahaan terhadap ERC}

Dari hasil uji t, dapat disimpulkan tidak tolak Ho atau tidak terdapat cukup bukti ukuran perusahaan berpengaruh secara signifikan terhadap earnings response coefficient. Hasil penelitian ini mengindikasikan bahwa sumber daya (aset berwujud maupun tidak berwujud) yang dimiliki perusahaan tidak terlalu diperhitungkan oleh investor. Karena, investor lebih tertarik dengan faktor lain selain ukuran suatu perusahaan yang didasarkan oleh total aset. Selain itu, perusahaan sampel dalam penelitian ini sebagian besar merupakan perusahaan kecil sehingga pasar akan menilai negatif variabel ukuran perusahaan. Karena, investor akan lebih tertarik dengan perusahaan besar.

\section{Kesimpulan}

Berdasarkan hasil analisis yang telah dilakukan dalam penelitian, maka kesimpulan dari hasil penelitian ini adalah sebagai berikut :

1. Persistensi laba terbukti berpengaruh positif signifikan terhadap earnings response coefficient. 
2. Peluang pertumbuhan terbukti berpengaruh negatif signifikan terhadap earnings response coefficient.

3. Struktur modal tidak terbukti berpengaruh signifikan terhadap earnings response coefficient.

4. Profitabilitas tidak terbukti berpengaruh signifikan earnings response coefficient.

5. Ukuran perusahaan tidak terbukti berpengaruh signifikan terhadap earnings response coefficient.

\section{Saran}

Berdasarkan kesimpulan dan hasil penelitian serta pembahasan yang dilakukan, penulis dapat memberikan saran sebagai berikut

1. Bagi investor.

Untuk menentukan keputusan investasi tentunya investor harus memilih terlebih dahulu untuk melakukan investasi jangka panjang untuk menghasilkan return berupa dividen atau investasi jangka pendek untuk menghasilkan capital gain. Dalam menentukan pilihan investasinya, investor disarankan untuk memperhatikan faktor-faktor yang mempengaruhi earnings response coefficient. Nilai earnings response coefficient yang besar menandakan bahwa respon pasar terhadap pengmuman informasi laba juga besar. Karena, earnings response coefficient menggambarkan tentang respon pasar yaitu melalui kekuatan hubungan laba dengan perubahan harga pada suatu perusahaan. Jadi, para investor disarankan untuk berinvestasi pada perusahaan yang memiliki earnings response coefficient tinggi.

2. Bagi pembaca.

Bagi para peneliti disarankan untuk :

a. Menggunakan sampel yang lebih besar atau meneliti di sektor lain seperti properti, perbankan, perdagangan atau lainnya yang terdapat di Bursa Efek Indonesia ( BEI).

b. Dapat menggunakan rentang waktu yang lebih panjang untuk menghasilkan penelitian yang baik. Semakin panjang rantang waktu akan semakin baik hasil penelitiannya.

c. Diharapkan untuk menggunakan variabel lain yang mempengaruhi earnings response coefficient seperti kualitas auditor, konservatisme akuntansi, likuiditas, corporate social responsibility (CSR) dan yang lainnya.

d. Mengganti / mengubah proksi pengolahan data seperti profitabilitas menggunakan return on equity (ROE) dan leverage menggunakan debt to equity ratio (DER) atau lain sebagainya.

\section{Daftar Pustaka}

Arif, R. (2016). Pengaruh Struktur Modal, Resiko Sistematis, Kesempatan Bertumbuh, dan Ukuran Perusahaan terhadap Earnings Response Coefficient (ERC) (Studi Pada Perusahaan Manufaktur yang Terdaftar di Bursa Efek Indonesia). Jurnal Akuntansi, Volume 4(2), 1-26.

Barney, J. (1991). Firm Resources and Sustained Competitive Advantage. Journal of Management, 17(1), 99-120.

Boediono, G. S. (2005). Kualitas Laba: Studi Pengaruh Mekanisme Corporate Governance dan Dampak Manajemen Laba Dengan Menggunakan Analisis Lajur. Simposium Nasional Akuntansi, VIII(September), 1-23.

Delvira, M., \& Nelvirita. (2013). Pengaruh Resiko Sistematik, Leverage dan Persistensi Laba Terhadap Earnings Response Coefficient (ERC) (Studi pada Perusahaan Manufaktur yang Go Public di BEI Tahun 2008-2010). Jurnal WRA, Volume 1(1), 129-154.

Diantimala, Y. (2008). Pengaruh Akuntansi Konservatif, Ukuran Perusahaan, dan Default Risk Terhadaap Koefisen Respon Laba ( ERC ). Jurnal Telaah \& Riset Akuntansi, 1(1), 102-122. 
Fitri, L. (2013). Pengaruh Ukuran Perusahaan, Kesempatan Bertumbuh, Dan Profitabilitas Terhadap Earnings Response Coefficient (Studi Empiris Pada Perusahaan Manufaktur yang Terdaftar Di Bursa Efek Indonesia (BEI) Tahun 20082011). Jurnal Akuntansi, Volume 1(3), 116.

Harahap, K. (2004). Asosiasi Antara Praktik Perataan Laba Dengan Koefisien Respon Laba. Simposium Nasional Akuntansi, 7, 1164-1176.

Hasanzade, M., Darabi, R., \& Mahfoozi, G. (2013). Factors Affecting the Earnings Response Coefficient: An Empirical study for Iran. European Online Journal of Natural and Social Sciences, 2(3), 25512560.

Hery. (2016). Financial Ratio for Business. Jakarta: PT. Grasindo.

Imroatussolihah, E. (2013). Ely Imroatussolihah; Pengaruh Risiko, Leverage ... Jurnal Ilmiah Manajemen, Volume 1 N(1 Januari 2013), 75-87.

Jaswadi. (2004). Dampak Earnings Reporting Lags Terhadap Koefisien Respon Laba. Jurnal Riset Akuntansi Indonesia, 7(3), 295-315.

Jensen, M., \& Meckling, W. (1976). Theory of The Firm: Managerial Behaviour, Agency Costs and Ownership Structure. Journal of Economics, Volume 3(4), 305-360.

Kallapur, S., \& Trombley, M. A. (2001). The Investment Opportunity Set : Determinants, Consequences and Measurement. Managerial Finance, 27(3), 3-15.

Kurnia, I., \& Sufiyati. (2015). Pengaruh Ukuran Perusahaan, Leverage. Resiko Sistematik. dan Investment Opporunity Set terhadap Earnings Response Coefficient pada Perusahaan Manufaktur yang Terdaftar di Bursa Efek Indonesia pada Tahun 2012-
2014. Jurnal Ekonomi, XX(3), 463-478.

Mahendra, I. P. Y., \& Wirama, D. G. (2017). Pengaruh Profitabilitas, Struktur Modal dan Ukuran Perusahaan pada Earnings Response Coefficient. Jurnal Akuntansi, 20(3), 2566-2594.

Mashayekhi, B., \& Aghel, Z. L. (2016). A Study on the Determinants of Earnings Response Coefficient in an Emerging Market. International Journal of Economics and Management Engineering, 10(7), 24792482.

Mulyani, S., Asyik, N. F., \& Andayani. (2007). Faktor - Faktor yang Mempengaruhi Earnings Response Coefficient pada Perusahaan yang Terdaftar di Bursa Efek Jakarta. JAAI, Volume 11(1), 35-45.

Novianti, R. (2012). Kajian Kualitas Laba pada Perusahaan Manufaktur yang Terdaftar di BEI. Accounting Analysis Journal, Volume 1(2), Hal: 1-6.

Nurhanifah, Y. A., \& Jaya, T. E. (2014). Pengaruh Alokasi Pajak Antar Periode, Investment Opportunity Set, dan Likuiditas terhadap Kualitas Laba. Jurnal Ilmiah Wahana Akuntansi, Volume 9(2), 109-133.

Penman, S. H., \& Zhang, X.-J. (2006). Accounting Conservatism, the Quality of Earnings, and Stock Returns. The Accounting Review, 77(2), 237-264.

Ross, S. A. (1973). The Economic Theory of Agency: The Principal's Problem. The American Economic Review, 63(2), 134139.

Ross, S. A. (1977). The Determination of Financial Structure: The IncentiveSignalling Approach. Journal of Economics, 8(1), 23-40.

Sandi, K. U. (2013). Faktor - Faktor yang Mempengaruhi Earnings Response Coefficient. Accounting Analysis Journal, 
2(3), 337-344.

Setiati, F., \& Kusuma, I. W. (2004). Faktorfaktor Yang Mempengaruhi Koefisien Respon Laba pada Perusahaan Bertumbuh dan Tidak Bertumbuh. Simposium Nasional Akuntansi, VII.

Smith, C. W., \& Watts, R. L. (1992). The Investment Opportunity Set and Corporate Financing, Dividend, and Compensation Policies. Journal of Financial Economics, 32, 263-292.

Suaryana, A. (2005). Pengaruh Komite Audit terhadap Kualitas Laba. SNA, VIII, 147158.

Suhartono, S. (2015). Pengaruh Ukuran Perusahaan, Struktur Modal, dan Ketepatan Waktu Penyampaian Laporan Keuangan terhadap Koefisien Respon Laba yang di Moderasi Konservatisme Akuntansi. Jurnal Akuntansi Keuangan, 22(2), 189-216.

Suwito, E., \& Herawaty, A. (2005). Analisis
Pengaruh Karakteristik Perusahaan terhadap Tindakan Perataan Laba yang Dilakukan oleh Perusahaan yang Terdaftar di Busra Efek Jakarta. SNA, 8, 136-146.

Syafrina, W. (2017). Faktor - Faktor yang Mempengaruhi Koefisien Respon Laba pada Perusahaan Manufaktur yang Terdaftar di BEI. Jurnal Akuntansi, 6(2), 194-210.

Tiolemba, N., \& Ekawati, E. (2008). Analisis Faktor-Faktor yang Mempengaruhi Koefisien Respon Laba pada Perusahaan Manufaktur yang Terdaftar di BEJ. Jurnal Riset Akuntansi Dan Keuangan, Volume 4(2), 100-115.

Wernerfelt, B. (1984). A Resource-based View of the Firm. Strategic Management Journal, 5(2), 171-180.

Wulansari, Y. (2013). Pengaruh Investment Opportunity Set, Likuiditas Dan Leverage Terhadap Kualitas Laba Pada Perusahaan Manufaktur Yang Terdaftar Di BEI. Jurnal Akunansi, Volume 1(2), 1-31. 


\section{LAMPIRAN}

\section{Uji Statistika Deskriptif}

Descriptive Statistics

\begin{tabular}{|l|r|r|r|r|r|}
\hline & \multicolumn{1}{|c|}{$\mathrm{N}$} & Minimum & Maximum & \multicolumn{1}{c|}{ Mean } & Std. Deviation \\
\hline ERC & 31 & -.5947 & .9007 & .049835 & .2429032 \\
PL & 31 & -.4554 & 1.9738 & .399706 & .5358129 \\
IOS & 31 & .4815 & 19.3208 & 2.923194 & 4.0703967 \\
LEV & 31 & .1129 & .6836 & .399690 & .1680913 \\
ROA & 31 & .0015 & .4012 & .103858 & .1003057 \\
SIZE & 31 & 26.2054 & 33.2445 & 28.785539 & 1.7733739 \\
Valid N & 31 & & & & \\
(listwise) & & & & \\
\hline
\end{tabular}

\section{Uji Analisis Regresi Berganda}

Coefficients $^{\mathbf{a}}$

\begin{tabular}{|c|c|c|c|c|c|c|}
\hline \multirow{2}{*}{\multicolumn{2}{|c|}{ Model }} & \multicolumn{2}{|c|}{ Unstandardized Coefficients } & \multirow{2}{*}{$\begin{array}{c}\begin{array}{c}\text { Standardized } \\
\text { Coefficients }\end{array} \\
\text { Beta }\end{array}$} & \multirow[t]{2}{*}{$\mathrm{t}$} & \multirow[t]{2}{*}{ Sig. } \\
\hline & & B & Std. Error & & & \\
\hline \multirow{6}{*}{1} & (Constant) & .632 & .661 & & .957 & .348 \\
\hline & PL & .194 & .084 & .429 & 2.302 & .030 \\
\hline & IOS & -.042 & .018 & -.701 & -2.278 & .032 \\
\hline & LEV & .104 & .247 & .072 & .419 & .678 \\
\hline & ROA & .106 & .720 & .044 & .147 & .884 \\
\hline & SIZE & -.021 & .023 & -.150 & -.879 & .388 \\
\hline
\end{tabular}

a. Dependent Variable: ERC

\section{Uji Normalitas}

One-Sample Kolmogorov-Smirnov Test

\begin{tabular}{|ll|r|}
\hline & & $\begin{array}{r}\text { Unstandardize } \\
\text { d Residual }\end{array}$ \\
\hline N & Mean & 31 \\
Normal Parameters & aE- \\
& Std. Deviation & .19160881 \\
Most Extreme & Absolute & .132 \\
Differences & Positive & .132 \\
Kolmogorov-Smirnov Z & Negative & -.064 \\
Asymp. Sig. (2-tailed) & & .737 \\
\hline
\end{tabular}

a. Test distribution is Normal.

b. Calculated from data. 
4. Uji Heteroskedastisitas

Coefficients $^{\mathbf{a}}$

\begin{tabular}{|c|c|c|c|c|c|c|}
\hline \multirow{2}{*}{\multicolumn{2}{|c|}{ Model }} & \multicolumn{2}{|c|}{ Unstandardized Coefficients } & \multirow{2}{*}{$\begin{array}{c}\begin{array}{c}\text { Standardized } \\
\text { Coefficients }\end{array} \\
\text { Beta }\end{array}$} & \multirow[t]{2}{*}{$\mathrm{t}$} & \multirow[t]{2}{*}{ Sig. } \\
\hline & & $\mathrm{B}$ & Std. Error & & & \\
\hline \multirow{6}{*}{1} & (Constant) & .458 & .389 & & 1.177 & .250 \\
\hline & PL & .098 & .050 & .402 & 1.976 & .059 \\
\hline & IOS & .017 & .011 & .525 & 1.560 & .131 \\
\hline & LEV & .022 & .146 & .029 & .153 & .879 \\
\hline & ROA & -.633 & .424 & -.486 & -1.494 & .148 \\
\hline & SIZE & -.012 & .014 & -.166 & -.889 & .382 \\
\hline
\end{tabular}

a. Dependent Variable: Res_2

\section{Uji Multikolinearitas}

\begin{tabular}{|c|c|c|c|c|c|c|c|}
\hline \multirow[t]{2}{*}{ Model } & \multicolumn{2}{|c|}{$\begin{array}{l}\text { Unstandardized } \\
\text { Coefficients }\end{array}$} & \multirow{2}{*}{$\begin{array}{c}\begin{array}{c}\text { Standardized } \\
\text { Coefficients }\end{array} \\
\text { Beta }\end{array}$} & \multirow[t]{2}{*}{$\mathrm{t}$} & \multirow[t]{2}{*}{ Sig. } & \multicolumn{2}{|c|}{ Collinearity Statistics } \\
\hline & B & Std. Error & & & & Tolerance & VIF \\
\hline (Constant) & .632 & .661 & & .957 & .348 & & \\
\hline PL & .194 & .084 & .429 & 2.302 & .030 & .718 & 1.393 \\
\hline IOS & -.042 & .018 & -.701 & -2.278 & .032 & .263 & 3.804 \\
\hline LEV & .104 & .247 & .072 & 419 & .678 & .849 & 1.178 \\
\hline ROA & .106 & .720 & .044 & .147 & .884 & .281 & 3.556 \\
\hline SIZE & -.021 & .023 & -.150 & -.879 & .388 & .858 & 1.165 \\
\hline
\end{tabular}

a. Dependent Variable: ERC

6. Uji Autokorelasi

Runs Test

\begin{tabular}{|l|r|}
\hline & $\begin{array}{c}\text { Unstandardize } \\
\text { d Residual }\end{array}$ \\
\hline Test Value & -.01208 \\
Cases < Test Value & 15 \\
Cases >= Test Value & 16 \\
Total Cases & 31 \\
Number of Runs & 11 \\
Z & -1.823 \\
Asymp. Sig. (2- & .068 \\
tailed) & \\
\hline
\end{tabular}

a. Median 
7. Uji F

ANOVA ${ }^{\mathrm{a}}$

\begin{tabular}{|rl|r|r|r|r|r|}
\hline \multicolumn{1}{|l|}{ Model } & \multicolumn{1}{c|}{$\begin{array}{c}\text { Sum of } \\
\text { Squares }\end{array}$} & df & Mean Square & F & Sig. \\
\hline \multirow{2}{*}{1} & Regression & .669 & 5 & .134 & 3.035 & $.028^{\mathrm{b}}$ \\
& Residual & 1.101 & 25 & .044 & & \\
\cline { 2 - 5 } & Total & 1.770 & 30 & & & \\
\hline
\end{tabular}

a. Dependent Variable: ERC

b. Predictors: (Constant), SIZE, LEV, ROA, PL, IOS

\section{Uji-t}

Coefficients $^{\mathbf{a}}$

\begin{tabular}{|c|c|c|c|c|c|c|}
\hline \multirow{2}{*}{\multicolumn{2}{|c|}{ Model }} & \multicolumn{2}{|c|}{ Unstandardized Coefficients } & \multirow{2}{*}{$\begin{array}{c}\begin{array}{c}\text { Standardized } \\
\text { Coefficients }\end{array} \\
\text { Beta }\end{array}$} & \multirow[t]{2}{*}{$\mathrm{t}$} & \multirow[t]{2}{*}{ Sig. } \\
\hline & & B & Std. Error & & & \\
\hline \multirow{6}{*}{1} & (Constant) & .632 & .661 & & 957 & .348 \\
\hline & PL & .194 & .084 & .429 & 2.302 & .030 \\
\hline & IOS & -.042 & .018 & -.701 & -2.278 & .032 \\
\hline & LEV & .104 & .247 & .072 & .419 & .678 \\
\hline & ROA & .106 & .720 & .044 & .147 & .884 \\
\hline & SIZE & -.021 & .023 & -.150 & -.879 & .388 \\
\hline
\end{tabular}

a. Dependent Variable: ERC

\section{Uji Koefisien Determinasi}

Model Summary

\begin{tabular}{|l|r|r|r|r|}
\hline Model & \multicolumn{1}{|c|}{$\mathrm{R}$} & R Square & $\begin{array}{c}\text { Adjusted R } \\
\text { Square }\end{array}$ & $\begin{array}{c}\text { Std. Error of } \\
\text { the Estimate }\end{array}$ \\
\hline 1 & $.615^{\mathrm{a}}$ & .378 & .253 & .2098969 \\
\hline
\end{tabular}

a. Predictors: (Constant), SIZE, LEV, ROA, PL, IOS 